\title{
SERUM SOLUBLE CD25 IN HEPATOCELLULAR CARCINOMA, SHALL WE BE ABLE TO CHANGE THE NATURAL HISTORY?
}

\author{
${ }^{1}$ E. A. Sameea, ${ }^{1 T}$. Zakareya, ${ }^{1} \mathrm{~K}$. Metwaly, \\ ${ }^{2}$ A. A.-R. Youssef, ${ }^{2}$ H. M. Kamal, ${ }^{2}$ W. M. Abdalla \\ ${ }^{1}$ HEPATOLOGY DEPARTMENT, NATIONAL LIVER INSTITUTE, MENOUFIVA UNIVERSITY, EGYPT \\ ${ }^{2}$ CLINICAL AND CHEMICAL PATHOLOGY DEPARTMRNT, BANHA FACULTY OF MEDICINE, EGYPT
}

Background. Although hepatocellular carcinoma (HCC) is one of the most common malignancy related mortality worldwide, it can be curable if detected in early stages. Emergence of a new marker that can early detect HCC could help in early treatment and therefore ameliorate the outcome.

Objective. The aim of the research is to evaluate the performance of serum soluble CD25 (sCD25) in the prediction of early HCC and compare it to a-fetoprotein (AFP).

Methods. Serum levels of SCD25 and AFP were measured in three groups of population; HCC group (40 patients), cirrhosis without HCC control group (20 patients) and healthy control group (20 patients). HCC group contained 20 early and 20 late stage patients according to Barcelona Clinic Liver Cancer (BCLC) staging system (stage $0 / A$ and $B-D$ respectively). Levels of both biomarkers were compared in all groups. Predictive yield of both biomarkers for early HCC was evaluated using ROC curve analysis.

Results. Level of SCD25 was significantly higher in patients with HCC than in both cirrhotic controls and healthy controls $(P<0.0001$ and 0.013 respectively). For prediction of early HCC in patients with cirrhosis, the optimal sCD25 cut-off level was $7.15 \mathrm{ng} / \mathrm{ml}$ with sensitivity and specificity of $90 \%$ and $60 \%$ respectively $(A \cup C=0.717$; $P=0.019)$ while sensitivity and specificity of AFP were $70 \%$ and $85 \%$ respectively at a cut-off value of $9.85 \mathrm{ng} / \mathrm{ml}$ ( $A \cup C=0.781 ; P=0.002)$ in the same settings.

Conclusion. SCD25 seems to be a reliable biomarker for early detection of HCC and therefore could enhance the outcome.

KEY WORDS: hepatocellular carcinoma; soluble CD25; alfa fetoprotein.

\section{Introduction}

Hepatocellular carcinoma is one of the most serious and life threatening complications of chronic liver disease. It represents the $5^{\text {th }}$ most common malignancy in men, the $7^{\text {th }}$ in women and the $3^{\text {rd }}$ malignancy related mortality worldwide. Curative treatment strategy can be achieved if detected in early stages [1-4]. The role of serum a-fetoprotein (AFP), the widely used classical biomarker for HCC, has been stepped down in the recent European and American surveillance guidelines because of low sensitivity and specificity. This is based on the knowledge that almost $80 \%$ of small HCCs do not show increased levels of AFP, and the sensitivity decreases to $25 \%$ in tumors smaller than $3 \mathrm{~cm}$ [5-8]. Looking for a new marker with a better

Corresponding author: Talaat Zakareya, Department of Hepatology, National Liver Institute, Menoufiya University, Shebeen El-Kom, Menoufiya, Egypt, 32511

Phone number: +201111815877

E-mail: talaatzakareya@gmail.com diagnostic accuracy became an inevitable requirement. This eventually would optimize the HCC surveillance program and improve the outcome through prompt application of the proper treatment strategy early in the course of the disease. Serum soluble CD25 (sCD25) has been recently investigated as a new marker for hepatocellular carcinoma. It quantitatively reflects the immunological activity against the tumor [9-11]. It represents the a-chain of interleukin 2 receptor (IL-2Ra) which is composed of three polypeptide chains: $\alpha, \beta$ and $y$. It is not found on the surface of resting $T$ cells, but rapidly expressed on their surface after being activated. Chronic T-cell stimulation, as in some malignancies, leads to shedding of IL-2Ra (CD25) into plasma with subsequent elevation of its level [11-16]. Cabrena and colleagues reported that serum level of SCD25 was correlating with tumor burden and poor survival in HCC patients and believed that measuring 
serum level of SCD25 might provide a clue for early diagnosis of HCC [12]. When we designed the current study, we hypothesized that SCD25 could have an impressive diagnostic value and a potential ability for detection of early HCC. We assessed the performance of sCD25 in the prediction of early HCC and its correlation with the tumor stage and compare it with AFP.

\section{Methods}

The study was conducted in National Liver Institute, Menoufiya, Egypt. After obtaining an informed consent, eighty persons in 3 groups were included; HCC on a background of cirrhosis (40 patients), liver cirrhosis with no evidence of HCC (20 patients) and healthy control group (20 patients). HCC group comprised 20 early and 20 late stage HCC patients, according to Barcelona Clinic Liver Cancer (BCLC) staging system, (stage A and B-D respectively) (Fig. 1). Cirrhotic and healthy controls had matched age and sex with HCC patients. All included cases of HCC was diagnosed on the basis of the presence of typical vascular enhancement pattern of liver lesion (s) in contrast enhanced dynamic CT scan or MRI [18]. Diagnosis of cirrhosis was based on combined historical, clinical, laboratory and radiological findings. Severity of cirrhosis was assessed by Child Pugh classification [19]. All patients had complete laboratory profile including $C B C$, liver panel, creatinin as well as serum level of sCD25 and AFP. ELISA kit (Elecsys E411, Switzerland) was used to quantify blood level of AFP while ELISA kit (Bender MedSystems, Vienna, Austaria) was used to measure serum level of SCD25.

Statistical methods

SPSS, version 21 for Windows (Inc, Chicago, IL, USA) was used for all statistical analyses. Qualitative data were presented as frequency and percentage. Chi square and Fisher's exact tests were used to compare groups. Quantitative data were presented as mean and standard deviation. For non-parametric data, Student t-test and Mann-Whitney $U$ test were used to compare level difference of sCD25 between two groups while ANOVA and Kruskal Wallis were used to compare level difference of sCD25 between more than two groups. Receiver-operator characteristic (ROC) curve analysis was used to generate sensitivity and specificity at different cut-offs. The best cut-off was set at the value where sensitivity and specificity were maximal. Correlation between serum level of sCD25 and laboratory parameters was assessed by Spearman's correlation coefficient. The statistical significance was set at P-value of less than 0.05 for all tests.

\section{Results}

The studied populations were mostly males representing $77.5,75$ and $60 \%$ in HCC, cirrhotic and healthy control groups respectively. The mean age was $56.38 \pm 5.934$ years in HCC group while was $53.75 \pm 7.383$ and $54.20 \pm 5.863$ years in cirrhotic and healthy controls respectively. Hepatitis c virus (HCV) was the underlying etiology of cirrhosis in all patients in both HCC and cirrhotic control groups. The mean SCD25 level was $13.07 \pm 6.645,13.15 \pm 6.967,8.938 \pm 6.487$ and $4.97 \pm 3.031 \mathrm{ng} / \mathrm{ml}$ in early HCC, late HCC, cirrhotic and healthy control groups respectively. Level of SCD25 was significantly higher in patients with HCC than in both cirrhotic and healthy controls $(p<0.0001$ and 0.013 respectively) and significantly higher in cirrhotic patients than healthy controls ( $p=0.042)$. sCD25 level was significantly and positively correlated with the severity of liver disease as assessed by Child-Pugh classification $(r=0.56, p<0.001)$. There was no statistical difference between sCD25 in early and late HCC $(p=0.968)$. The mean AFP level was $17.66 \pm 12.092,244 \pm 302.041$, $8.01 \pm 6.965$ and $2.95 \pm 2.175 \mathrm{ng} / \mathrm{ml}$ in early HCC,

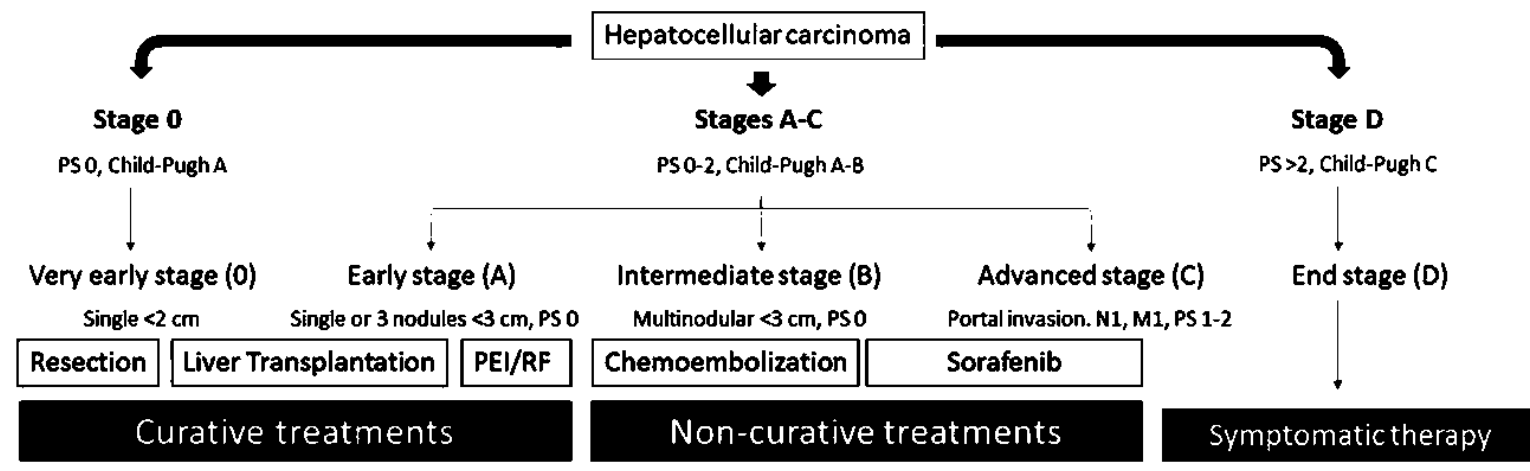

Fig. 1. Barcelona Clinic Liver Cancer (BCLC) staging and treatment strategy (Adapted from Llovet JM, et al. Lancet 2003) [17]. PS - performance status; PEI - percutaneous ethanol injection; RF - radiofrequency 
Table 1. Statistical difference of demographic and laboratory data among the studied groups

\begin{tabular}{|c|c|c|c|c|c|c|c|c|c|c|}
\hline & & $\begin{array}{l}\text { Total } \\
\text { HCC } \\
(n=40)\end{array}$ & $\begin{array}{c}\text { Early } \\
\text { HCC } \\
(n=20)\end{array}$ & $\begin{array}{l}\text { Late HCC } \\
\quad(n=20)\end{array}$ & $\begin{array}{c}\text { LC } \\
(n=20)\end{array}$ & $\begin{array}{c}\text { Healthy } \\
\text { control } \\
(n=20)\end{array}$ & $p$ & $p^{*}$ & $p^{\wedge}$ & $p^{\#}$ \\
\hline \multirow{2}{*}{$\begin{array}{l}\text { Sex } \\
\text { n (\%) }\end{array}$} & $0^{x} S$ & $31(77.5)$ & $15(75)$ & $16(80)$ & $15(75)$ & $12(60)$ & \multirow{2}{*}{0.156} & \multirow{2}{*}{0.311} & \multirow{2}{*}{0.829} & \multirow{2}{*}{0.705} \\
\hline & is & $9(22.5)$ & $5(25)$ & $4(20)$ & $5(25)$ & $8(40)$ & & & & \\
\hline \multirow{2}{*}{\multicolumn{2}{|c|}{ Age (years) }} & \multicolumn{5}{|c|}{ Mean \pm SD } & \multirow[b]{2}{*}{0.212} & \multirow[b]{2}{*}{0.822} & \multirow[b]{2}{*}{0.133} & \multirow[b]{2}{*}{0.539} \\
\hline & & $\begin{array}{c}56.38 \pm \\
5.934\end{array}$ & $\begin{array}{c}58.40 \pm \\
5.576\end{array}$ & $\begin{array}{c}55.35 \pm \\
5.706\end{array}$ & $\begin{array}{c}53.75 \pm \\
7.383 \\
\end{array}$ & $\begin{array}{c}54.20 \pm \\
5.863\end{array}$ & & & & \\
\hline \multicolumn{2}{|l|}{$\mathrm{Hb}(\mathrm{g} / \mathrm{dl})$} & $\begin{array}{c}11.07 \pm \\
1.097 \\
\end{array}$ & $\begin{array}{c}11.14 \pm \\
1.268 \\
\end{array}$ & $\begin{array}{c}11.01 \pm \\
0.925\end{array}$ & $\begin{array}{c}10.52 \pm \\
0.928 \\
\end{array}$ & $\begin{array}{c}12.71 \pm \\
1.091 \\
\end{array}$ & $<0.001$ & $<0.001$ & 0.058 & 0.724 \\
\hline \multicolumn{2}{|l|}{$\begin{array}{l}\text { WBCs } \\
(\times 103 / \mathrm{dl})\end{array}$} & $\begin{array}{l}4.88 \pm \\
1.717 \\
\end{array}$ & $\begin{array}{l}5.18 \pm \\
2.247 \\
\end{array}$ & $\begin{array}{l}4.59 \pm \\
0.903\end{array}$ & $\begin{array}{l}4.87 \pm \\
1.242 \\
\end{array}$ & $\begin{array}{l}7.00 \pm \\
1.693 \\
\end{array}$ & $<0.001$ & $<0.001$ & 0.977 & 0.282 \\
\hline \multicolumn{2}{|l|}{$\begin{array}{l}\text { Platelets } \\
(\times 103 / d l)\end{array}$} & $\begin{array}{c}119.65 \pm \\
35.246\end{array}$ & $\begin{array}{c}122.55 \pm \\
34.264\end{array}$ & $\begin{array}{c}116.75 \pm \\
36.854\end{array}$ & $\begin{array}{c}169.05 \pm \\
31.749\end{array}$ & $\begin{array}{c}217.80 \pm \\
47.522\end{array}$ & $<0.001$ & $<0.001$ & $<0.001$ & 0.609 \\
\hline \multicolumn{2}{|l|}{ INR } & $\begin{array}{l}1.37 \pm \\
0.196 \\
\end{array}$ & $\begin{array}{l}1.43 \pm \\
0.197\end{array}$ & $\begin{array}{l}1.32 \pm \\
0.185\end{array}$ & $\begin{array}{l}1.31 \pm \\
0.236\end{array}$ & $\begin{array}{l}1.07 \pm \\
0.081\end{array}$ & $<0.001$ & $<0.001$ & 0.225 & 0.091 \\
\hline \multicolumn{2}{|c|}{ Albumin (g/dl) } & $\begin{array}{l}3.19 \pm \\
0.371\end{array}$ & $\begin{array}{c}3.334 \pm \\
0.382 \\
\end{array}$ & $\begin{array}{l}3.04 \pm \\
0.299 \\
\end{array}$ & $\begin{array}{l}3.55 \pm \\
0.445\end{array}$ & $\begin{array}{l}4.34 \pm \\
0.463 \\
\end{array}$ & $<0.001$ & $<0.001$ & 0.002 & 0.009 \\
\hline \multicolumn{2}{|l|}{$\begin{array}{l}\text { Bilirubin } \\
\text { (mg/dl) }\end{array}$} & $\begin{array}{l}1.64 \pm \\
0.833\end{array}$ & $\begin{array}{l}1.19 \pm \\
0.415\end{array}$ & $\begin{array}{l}2.09 \pm \\
0.907\end{array}$ & $\begin{array}{l}1.73 \pm \\
0.692\end{array}$ & $\begin{array}{l}0.84 \pm \\
0.154\end{array}$ & $<0.001$ & $<0.001$ & 0.626 & $<0.001$ \\
\hline \multicolumn{2}{|l|}{$\operatorname{ALT}(\mathrm{U} / \mathrm{ml})$} & $\begin{array}{l}65.15 \pm \\
15.184 \\
\end{array}$ & $\begin{array}{l}61.75 \pm \\
17.278 \\
\end{array}$ & $\begin{array}{l}68.55 \pm \\
12.262 \\
\end{array}$ & $\begin{array}{l}57.05 \pm \\
10.655 \\
\end{array}$ & $\begin{array}{c}24.45 \pm \\
5.276 \\
\end{array}$ & $<0.001$ & $<0.001$ & $<0.001$ & 0.159 \\
\hline \multicolumn{2}{|l|}{ AST (U/ml) } & $\begin{array}{l}89.48 \pm \\
24.724 \\
\end{array}$ & $\begin{array}{l}76.50 \pm \\
17.021 \\
\end{array}$ & $\begin{array}{c}102.45 \pm \\
24.708\end{array}$ & $\begin{array}{l}67.85 \pm \\
10.069 \\
\end{array}$ & $\begin{array}{c}27.25 \pm \\
4.962 \\
\end{array}$ & $<0.001$ & $<0.001$ & 0.019 & $<0.001$ \\
\hline \multicolumn{2}{|l|}{$\begin{array}{l}\text { Creatinin } \\
(\mathrm{mg} / \mathrm{dl})\end{array}$} & $\begin{array}{l}0.93 \pm \\
0.159\end{array}$ & $\begin{array}{l}0.93 \pm \\
0.180\end{array}$ & $\begin{array}{l}0.94 \pm \\
0.139\end{array}$ & $\begin{array}{l}0.95 \pm \\
0.161\end{array}$ & $\begin{array}{l}1.04 \pm \\
0.193\end{array}$ & 0.025 & 0.114 & 0.665 & 0.845 \\
\hline \multicolumn{2}{|l|}{$\begin{array}{l}\text { sCD25 } \\
\text { (ng/ml) }\end{array}$} & $\begin{array}{c}13.11 \pm \\
6.719 \\
\end{array}$ & $\begin{array}{c}13.07 \pm \\
6.645 \\
\end{array}$ & $\begin{array}{c}13.15 \pm \\
6.967 \\
\end{array}$ & $\begin{array}{c}8.938 \pm \\
6.487 \\
\end{array}$ & $\begin{array}{l}4.97 \pm \\
3.031 \\
\end{array}$ & $<0.001$ & 0.042 & 0.013 & 0.968 \\
\hline \multicolumn{2}{|l|}{ AFP (ng/ml) } & $\begin{array}{l}130.83 \pm \\
240.106 \\
\end{array}$ & $\begin{array}{l}17.66 \pm \\
12.092 \\
\end{array}$ & $\begin{array}{c}244 \pm \\
302.041 \\
\end{array}$ & $\begin{array}{l}8.01 \pm \\
6.965 \\
\end{array}$ & $\begin{array}{l}2.95 \pm \\
2.175 \\
\end{array}$ & 0.008 & 0.926 & 0.010 & 0.003 \\
\hline \multirow{3}{*}{$\begin{array}{l}\text { Child-Pugh } \\
\text { score } \\
\mathrm{n}(\%)\end{array}$} & $\mathrm{A}$ & $6(15)$ & $6(30)$ & $0(0)$ & $12(60)$ & \multirow{3}{*}{ NA } & \multirow{3}{*}{ NA } & \multirow{3}{*}{ NA } & \multirow{3}{*}{0.001} & \multirow{3}{*}{0.004} \\
\hline & $\mathrm{B}$ & $29(72.5)$ & $14(70)$ & $15(75)$ & $8(40)$ & & & & & \\
\hline & $\mathrm{C}$ & $5(12.5)$ & $0(0)$ & $5(25)$ & $0(0)$ & & & & & \\
\hline
\end{tabular}

AFP - a-fetoprotein; Hb - hemoglobin; HCC - hepatocellular carcinoma; INR - international normalized ratio; LC - liver cirrhosis; NA - not applicable; $p$-significance between HCC and healthy controls; $p^{*}$ - significance between liver cirrhosis and healthy controls; $p^{\wedge}$ - significance between HCC and liver cirrhosis; $p^{\#}$ - significance between early and late HCC; sCD25 - soluble CD25; ơ s - males; is - females.

Table 2. Correlation between SCD25 and laboratory parameters among the studied groups

\begin{tabular}{|l|c|c|c|c|c|c|c|c|c|c|}
\hline & \multicolumn{2}{|c|}{$\begin{array}{c}\text { Total HCC } \\
(\mathrm{n}=40)\end{array}$} & \multicolumn{2}{c|}{$\begin{array}{c}\text { Early HCC } \\
(\mathrm{n}=20)\end{array}$} & \multicolumn{2}{c|}{$\begin{array}{c}\text { Late HCC } \\
(\mathrm{n}=20)\end{array}$} & \multicolumn{2}{c|}{$\begin{array}{c}\text { LC } \\
(\mathrm{n}=20)\end{array}$} & \multicolumn{2}{c|}{$\begin{array}{c}\text { Control } \\
(\mathrm{n}=20)\end{array}$} \\
\cline { 2 - 11 } & $r$ & $p$ & $r$ & $p$ & $r$ & $p$ & $r$ & $p$ & $r$ & $p$ \\
\hline $\mathrm{Hb}(\mathrm{g} / \mathrm{dl})$ & -0.060 & 0.714 & -0.038 & 0.875 & 0.040 & 0.866 & 0.304 & 0.193 & $-0.371-$ & 0.118 \\
\hline WBCs $\left(\times 10^{3} / \mathrm{dl}\right)$ & -0.228 & 0.157 & -0.478 & 0.033 & -0.063 & 0.792 & -0.081 & 0.736 & 0.179 & 0.462 \\
\hline Platelets $\left(\times 10^{3} / \mathrm{dl}\right)$ & 0.128 & 0.431 & 0.068 & 0.777 & 0.290 & 0.215 & -0.136 & 0.567 & -0.269 & 0.265 \\
\hline INR & 0.151 & 0.352 & 0.250 & 0.287 & 0.039 & 0.869 & -0.224 & 0.343 & 0.035 & 0.887 \\
\hline Albumin $(\mathrm{g} / \mathrm{dl})$ & 0.002 & 0.991 & 0.205 & 0.387 & -0.220 & 0.352 & 0.142 & 0.550 & 0.064 & 0.794 \\
\hline Bilirubin $(\mathrm{mg} / \mathrm{dl})$ & -0.038 & 0.816 & -0.102 & 0.668 & -0.021 & 0.928 & -0.442 & 0.051 & 0.266 & 0.270 \\
\hline ALT $(\mathrm{U} / \mathrm{ml})$ & 0.093 & 0.570 & 0.078 & 0.745 & 0.049 & 0.838 & -0.014 & 0.955 & 0.348 & 0.144 \\
\hline AST $(\mathrm{U} / \mathrm{ml})$ & 0.124 & 0.445 & 0.179 & 0.450 & 0.078 & 0.744 & -0.078 & 0.744 & 0.390 & 0.099 \\
\hline Creatinin $(\mathrm{mg} / \mathrm{dl})$ & 0.062 & 0.706 & 0.136 & 0.569 & -0.043 & 0.856 & -0.217 & 0.359 & -0.249 & 0.303 \\
\hline AFP $(\mathrm{ng} / \mathrm{ml})$ & 0.023 & 0.890 & 0.196 & 0.407 & -0.093 & 0.697 & -0.254 & 0.279 & 0.503 & 0.028 \\
\hline
\end{tabular}

AFP - a-fetoprotein; Hb - hemoglobin; HCC - hepatocellular carcinoma; INR - international normalized ratio; LC - liver cirrhosis; $r$ - Spearman's correlation coefficient. 
late HCC, cirrhotic and healthy control groups respectively with statistical difference between $\mathrm{HCC}$ versus cirrhotics and early versus late HCC as well ( $p=0.010$ and 0.003 respectively). The rest of demographic and laboratory data as well as their statistical differences between the studied groups are presented in Table 1. Correlation analyses between SCD25 and laboratory parameters among the studied groups are presented in Table 2. There was no significant correlation with all laboratory parameters apart from a negative correlation with WBCs in early HCC group $(r=-0.478, p=0.033)$ and a positive correlation with AFP in healthy control group $(r=-0.503, p=0.028)$. sCD25 performed well in predicting HCC presence among patients with cirrhosis; sensitivity and specificity were $90 \%$ and $84.2 \%$ respectively at a cut-off value of $7 \mathrm{ng} / \mathrm{ml}(A \cup C=0.969 ; p<0.0001)$. For prediction of early HCC in patients with cirrhosis, the optimal sCD25 cutoff level was $7.15 \mathrm{ng} / \mathrm{ml}$ with sensitivity and specificity of $90 \%$ and $60 \%$ respectively $(A \cup C=0.717 ; p=0.019)$ while, sensitivity and specificity of AFP were $70 \%$ and $85 \%$ respectively at a cut-off value of $9.85 \mathrm{ng} / \mathrm{ml}$ ( $A \cup C=0.781 ; p=0.002)$ in the same settings (Fig. 2).

\section{Discussion}

HCC represents the most serious and lethal complication of cirrhosis. Fortunately, early stages of HCC could be curative. Axiomatically, detection of HCC in early stages would be helpful in changing the poor outcome of late stages by offering the proper treatment early in the course of the disease with subsequent amelioration of the outcome [20-22]. In the current study, we evaluated the performance of SCD25 in predicting early HCC stages among patients with cirrhosis and compare it to AFP. Serum SCD25 level was significantly higher in HCC patients than cirrhotics $(p<0.0001)$ and healthy controls $(p=0.013)$. In the same stream, it was significantly higher in cirrhosis than healthy controls $(p=0.042)$. Additionally, there was a significant positive correlation between serum SCD25 and severity of cirrhosis (ChildPugh class) $(r=0.56, p<0.001)$. The optimal sCD25 cut-off level in detecting early HCC among cirrhotic patients was $7.15 \mathrm{ng} / \mathrm{ml}$ with sensitivity and specificity of $90 \%$ and $60 \%$ respectively ( $A \cup C=0.717 ; p=0.019$ ). On the other hand, sensitivity and specificity of AFP were $70 \%$ and $85 \%$ respectively at a cut-off value of $9.85 \mathrm{ng} / \mathrm{ml}$ (AUC=0.781; $\mathrm{p}=0.002$ ) in the same settings . This higher sensitivity of SCD25 highlights its substantial role as a screening marker for HCC. Similar findings were reported by Cabrena and his group. They reported SCD25 cut-off level of $2899 \mathrm{pg} / \mathrm{ml}$ as the best cut-off with a sensitivity of $89.6 \%$ and a specificity of $39.3 \%$ ( $A \cup C=0.630, p<0.0001)$. By comparison,

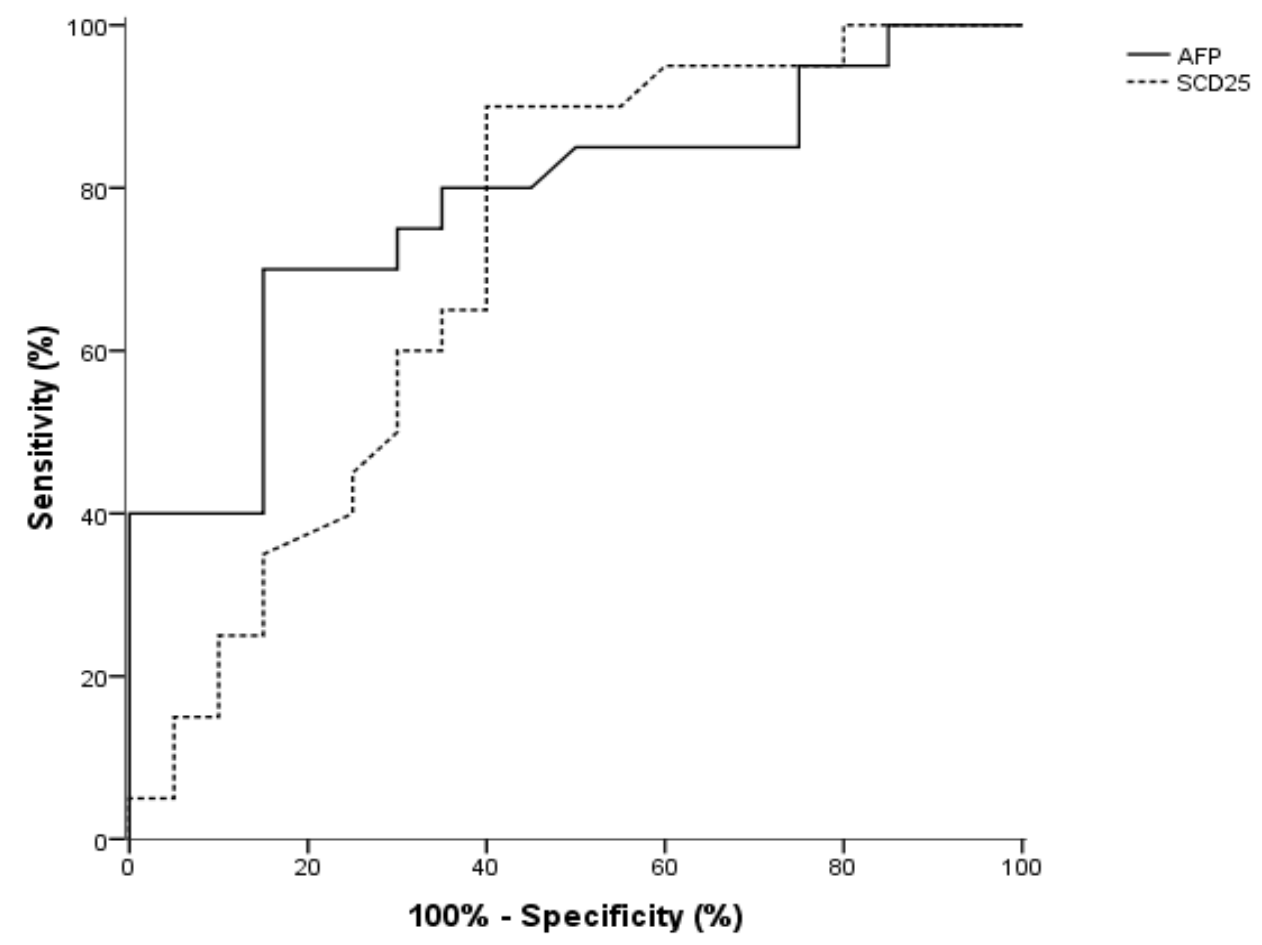

Fig. 2. Receiver operator curve (ROC) of SCD25 and AFP levels for the prediction of early HCC among patients with cirrhosis 
at a cut-off value of $20 \mathrm{ng} / \mathrm{ml}$, AFP had a sensitivity of $41.7 \%$ and a specificity of $82.6 \%$ ( $A \cup C=0.630, p=0.0257$ ) [12] The difference between the optimal cuto-ff between the current study $(7150 \mathrm{pg} / \mathrm{ml})$ and that of Cabrena et al. $(2899 \mathrm{pg} / \mathrm{ml})$ might be referred to the variability in the sample size, underlying etiology as well as dissimilarity in racial, ethnic, genetic and environmental factors. It is noteworthy that, the main underlying etiology of liver disease was HCV representing 92.5 and $90 \%$ in HCC and cirrhosis groups respectively while 7.5 and $10 \%$ were referred to combined $\mathrm{HCV}$ and HBV etiology in the same groups respectively. In the study of Cabrena et al., $60 \%$ were $\mathrm{HCV}, 13 \%$ were cryptogenic, $9 \%$ were alcoholic cirrhosis and 9\% were non-alcoholic fatty liver disease (NAFLD) in HCC group while $72 \%$ were $\mathrm{HCV}, 5 \%$ alcoholic cirrhosis and $5 \%$ NAFLD and 3\% were cryptogenic in cirrhosis group. In spite of the presence of a significant positive correlation between serum levels of sCD25 and severity of liver cirrhosis, there was no significant difference in its level in early and late HCC which disclaims findings of Cabrena et al., who reported a significant positive correlation between serum levels of SCD25 and tumor stage [12]. We could not eventually find a reasonable explanation for these conflicting results however difference in underlying etiology, tumor differentiation/biology, interracial and inter-ethnic variations between both studies might be accused. A notable finding that should be considered the correlation between SCD25 and AFP in HCC and cirrhosis groups was absent denoting that measuring both markers in serum can improve the reciprocally holistic diagnostic value of HCC.

\section{Conclusions}

Serum SCD25 sounds to be a good marker for predicting early HCC. There was some discrepancy between the optimal cut-off in the current and previous studies. This calls for a large scale study for further integration and unification of the current results and previous ones and to standardize the optimal cut-off taking into consideration addressing the relationship between sCD25 level and tumor biology rather than tumor size and number.
References

1. El-Serag HB. Epidemiology of viral hepatitis and hepatocellular carcinoma. Gastroenterology. 2012;142:1264-1273. e1. PMID: 22537432 DOI: 10.1053/j.gastro.2011.12.061.

2. El-Serag HB. Hepatocellular carcinoma. N Engl J Med. 2011;365:1118-1127.

3. Parkin DM, Bray F, Ferlay J, Pisani P. Estimating the world cancerburden: Globocan 2000. Int J Cancer. 2001;94:153-6.

4. Llovet JM, Burroughs A, Bruix J. Hepatocellular carcinoma. Lancet. 2003;362:1907-1917.

5. El-Serag HB, Kramer JR, Chen GJ, Duan Z, Richardson PA and Davila JA. Effectiveness of AFP and ultrasound tests on hepatocellular carcinoma mortality in HCV-infected patients in the USA. Gut. 2011;60:992-997.

6. Benowitz S. Liver cancer biomarkers struggling to succeed. J Natl Cancer Inst. 2007;99:590-591.

7. Sherman M. Current status of a-fetoprotein testing. GastroenterolHepatol (NY). 2011;7:113-114.

8. Bruix J, Sherman M. Management of hepatocellular carcinoma: an update. Hepatology 2011;53: 1020-1022. PMID: 21374666 DOI: 10.1002/hep.24199.
9. Cao M, Cabrera R, Xu Y, et al. Hepatocellular carcinoma cell supernatantsincrease expansion and function of CD4(+)CD25(+) regulatoryT cells. Lab Invest. 2007;87:582-90.

10. Foss FM. Immunologic mechanisms of antitumor activity. SeminOncol. 2002;29:5-11.

11. Cabrera R, Ararat M, Cao M, et al. Hepatocellular carcinoma immunopathogenesis:clinical evidence for global $\mathrm{T}$ cell defects and an immunomodulatory role for soluble CD25 (sCD25). Dig Dis Sci. 2010;55:484-95.

12. Cabrena R, Fitian A, Ararat M, et al. Serum levels of soluble CD25 as a marker for hepatocellular carcinoma. Oncology Letters. 2012;4:840-846.

13. Nakamoto Y, Guidotti LG, Kuhlen CV, Fowler $\mathrm{P}$, Chisari FV. Immune pathogenesis of hepatocellular carcinoma. J Exp Med. 1998;188:341-350.

14. Cacalano NA and Johnston JA: Interleukin-2 signaling and inherited immunodeficiency. Am J Hum Genet . 1999;65:287-293.

15. Hoechst B, Ormandy LA, Ballmaier $M$, et al. A new population of myeloid-derived suppressor cells in hepatocellular carcinoma patients induces 
CD4(+)CD25(+)Foxp3(+) T cells. Gastroenterology. 2008; 135:234-243.

16. Arun B, Curti BD, Longo DL, et al. Elevations in serum soluble interleukin-2 receptor levels predict relapse in patients with hairy cell leukemia. Cancer J Sci Am 6. 2000;21-24.

17. Forner A, Reig ME, de Lope CR, et al. Current strategy for staging and treatment: the BCLC update and future prospects. Semin. Liver Dis. 2010;30 (01):61-74.

18. Choi JY, Lee JM, Sirlin CB. CT and MR imaging diagnosis and staging of hepatocellular carcinoma: part I. Development, growth, and spread: key pathologic and imaging aspects. Radiology. 2014;272(3):635-54.
19. Pugh RN, Murray-Lyon IM, Dawson JL, Pietroni MC, Williams R. Transection of the oesophagus for bleeding oesophageal varices. Br J Surg. 1973; 60(8):646-9.

20. Fattovich G, Stroffolini T, Zagni I, Donato F. Hepatocellular carcinoma in cirrhosis: incidence and risk factors. Gastroenterology. 2004;127 Suppl 1: S35-S50.

21. Forner A, Llovet JM, Bruix J. Hepatocellular carcinoma. Lancet. 2012;379:1245-1255. PMID: 22353262 DOI: 10.1016/S0140-6736(11)61347-0.

22. Marrero JA. Current Treatment Approaches in HCC. Clin Adv Hematol Oncol. 2013;11 Suppl 5:15-18. 